\title{
PENINGKATAN MENULIS KARANGAN ARGUMENTASI KELAS VIII SMP 3 PAJJUKUKANG KABUPATEN BANTAENG MELALUI MEDIA GAMBAR SERI
}

\author{
Abdan Syakur ${ }^{1}$ dan Kaharuddin ${ }^{2}$ \\ Pendidikan Guru Sekolah Dasar, Universitas Muhammadiyah Makassar \\ abdan@unismuh.ac.id \\ Pendidikan Sosiologi, Universitas Muhammadiyah Makassar \\ kaharuddin@unismuh.ac.id
}

\begin{abstract}
Abstrak
Masalah utama dalam penelitian ini yaitu bagaimana menerapkan media gambar seri dalam meningkatkan kemampuan menulis karangan argumentasi kelas VIII SMP 3 Pajjukukang Kabupaten Bantaeng melalui media gambar seri. Penelitian ini bertujuan untuk meningkatkan kemampuan menulis karangan argumentasi siswa melalui media gambar seri. Jenis penelitian ini adalah penelitian tindakan kelas yang bertujuan untuk meningkatkan keterampilan menulis karangan argumentasi siswa melalui tindakan pemahaman konsep. Subjek penelitian ini adalah siswa kelas VIII melalui media gambar seri sebanyak 32 orang. Data keterampilan menulis karangan Argumentasi melalui media gambar seri melalui tes pada tiap akhir siklus. Data yang dikumpulkan dianalisis secara deskriptif dan ditentukan keterampilan menulis siswa berdasarkan pengkategorian keterampilan menulis karangan argumentasi siswa. Hasil penelitian menunjukkan dari siklus I ke siklus II menunjukkan bahwa keterampilan menulis karangan argumentasi siswa mengalami peningkatan dari siklus I ke siklus ke II. Hasil penelitian mengenai keterampilan Menulis Karangan Argumentasi melalui media gambar seri mengalami peningkatan dari siklus I ke siklus ke II. Pada siklus I rata-rata keterampilan menulis karangan argumentasi kelas VIII SMP 3 Pajjukukang Kabupaten Bantaeng pada siklus I yaitu sebesar 63, 13 meningkat pada siklus II menjadi 73, 59. Dengan demikian peneliti dapat menyimpulkan bahwa terjadi peningkatan kemampuan siswa kelas VIII SMP 3 Pajjukukang Kabupaten Bantaeng.
\end{abstract}

\section{Kata Kunci : Karangan Argumentasi , Media Gambar Seri}

\begin{abstract}
The main problem in this research is how to implement a series of images in the media improve argument essay writing class VIII SMP 3 Pajjukukang Bantaeng through a series of media imagery. This study aims to improve the ability to write an essay argumentation. This study is a class action that aims to improve the skills of writing essays argumentation the students through an act of understanding the concept. The subjects were students of class VIII through media picture series as many as 32 people. Data were analyzed descriptively and determine students' writing skills by writing argument essay categorization skills of students. Results showed from the first cycle to the second cycle shows that argumentasisiswa essay writing skills has increased from cycle I to cycle II. Results of research on argumentation skills Essay Writing class VIII SMP 3 Pajjukukang Bantaeng through a series of media imagery has increased from cycle I to cycle II. In the first cycle essay writing skills class average arguments SMP 3 Pajjukukang Bantaeng in the first cycle is equal to 63, 13 increased in the second cycle to 73, 59. Thus the researchers conclude that the increase in the ability of class VIII SMP 3 Pajjukukang Bantaeng.
\end{abstract}

Key words: Argumentation, Median, and picture 


\section{PENDAHULUAN}

Menulis dapat didefinisikan sebagai suatu kegiatan penyampaian pesan (komunikasi) dengan menggunakan bahasa tulis sabagi medianya (Suparno dan Yunus, 2003 : 3). Pesan adalah isi atau muatan yang terkandung dalam suatu tulisan. Tulisan merupakan sebuah simbol atau lambing bahasa yang dapat dilihat dan disepakati pemakainnya. Dengan demikian dalam komunikasi tulis paling tidak terdapat empat unsur yang terlibat : penulis sebagai penyampaian pesan, isi tulisan, saluran atau media berupa tulisan , dan pembaca sebagai penerima pesan.

Sebagai proses, menulis merupakan serangkaian aktivitas (kegiatan) yang terjadi dan melibatkan beberapa fase (tahap) yaitu fase pramenulis (persiapan), penulisan (pengembangan isi karangan), dan sesudah penulisan (revisi atau penyempurnaan tulisan).

Penguasaan terhadap menulis berarti kecakapan untuk mengetahui dan memahami struktur bahasa yang sesuai dengan kaidah yang berlaku. Kecakapan tersebut merupakan sebagian persyaratan keterampilan menulis seseorang untuk mengetahui, memahami, dan menggunakan unsur-unsur kata, kalimat, paragraf, serta tata tulis-menulis. Persyaratan kecakapan lain yang harus dimiliki oleh seorang penulis yang baik, seperti mencetuskan ide, mengorganisasi isi tulisan secara sistematis dan menerapkan kaidah-kaidah kebahasaan yang benar.

Belajar menulis yang baik memerlukan suatu metode. Salah satu metode yang dapat dipakai untuk itu adalah dengan latihan yang lama dan terus-menerus. Kualitas dari suatu teks tulisan sangat tergantung pada banyaknya waktu yang dipakai untuk menulis teks/tulisan tersebut. Standar rujukan untuk menulis sebuah esai dari seseorang membutuhkan waktu tidak kurang dari satu bulan.

Setelah peneliti menggunakan media gambar pada pelajaran menulis ada dua harapan yang akan ditinjau yakni harapan bagi siswa dan harapan bagi guru. Harapan bagi siswa yakni meningkatnya kemampuan menulis karangan argumentasidalam pembelajaran bahasa Indonesia. Hal ini disebabkan dengan media gambar diduga dapat menarik perhatian siswa yang beragam dalam membahasakannya.

Berdasarkan hasil wawancara dengan siswa Kelas VIII SMP 3 Pajjukukang Kabupaten Bantaeng disimpulkan bahwa hasil menulis karangan melalui media gambar seri masih sangat kurang sehingga perlu ditingkatkan.

Berdasarkan pengamatan peneliti terhadap siswa pada saat menulis karangan, siswa hanya dituliskan judulnya oleh guru. Kemudian siswa disuruh membuat karangan secara bebas artinya mengarang secara bebas. Kelihatannya anak sangat sukar saat akan menulis karangan. Hasil karangannya tidak disampaikan kepada siswa tentang hal-hal yang perlu diperbaiki. Berdasarkan latar belakang di atas, penulis tertarik untuk melakukan penelitian tindakan kelas khususnya menulis mengembangkan karangan argumentasidengan judul Peningkatan Menulis Karangan Argumentasi Kelas VIII SMP 3 Pajjukukang Kabupaten Bantaeng Melalui Media Gambar Seri.

\section{TELAAH PUSTAKA}

Secara harfiah kegiatan menulis dapat diartikan sebagai kegiatan yang menggambarkan bahasa dengan lambanglambang yang dapat dipahami, dalam hal ini Tarigan (1986 : 2) mengemukakan sebagai berikut : 
Menulis adalah mengemukakan atau melukiskan lambang-lambang grafik yang menggambarkan suatu bahasa yang dipahami oleh seseorang, sehingga orang lain dapat membaca lambing-lambang grafik tersebut kalau mereka memhammi bahasa dan gambaran grafik itu.

Dalam pembelajaran bahasa kemampuan menulis memiliki arti penting. Pertama, menulis dalam arti mengekspresikan pikiran dan perasaan dalam bahasa tulisan. Kedua, menulis dalam arti melahirkan bunyi-bunyi bahasa, ucapan-ucapan dalam bentuk tulisan. Dalam penelitian ini pengertian menulis berdasarkan pendapat yang pertama yaitu menulis sama dengan mengarang.

Berdasarkan pendapat di atas dapat disimpulkan bahwa yang dimaksud menulis atau mengarang adalah mengekspresikan pikiran, perasaan meliputi maksud, keinginan, informasi dalam bahasa tulisan yang tingkatannya paling tinggi.

Adapun bagian terpenting dalam menulis yaitu terdapat paragraf, karena paragraf merupakan bagian dari suatu karangan. Sedangkan pengertian paragraf menurut Tarigan (1981 : 1), adalah : Seperangkat kalimat tersusun logissistematis yang merupakan satu kesatuan ekspresi pikiran yang relevan dan mendukung pikiran pokok yang tersirat dalam keseluruhan karangan.

\section{Menulis sebagai Proses}

Kegiatan menulis merupakan kegiatan proses yaitu penulisan. Ini berarti bahwa kita melakukan kegiatan dalam beberapa tahap. Tahap-tahap menulis yaitu tahap pra penulisan dan tahap revisi.

Tahap pra penulisan merupakan tahap perencanaan atau persiapan menulis yang mencakup beberapa langkah kegiatan. Langkah-langkah yang harus dilakukan adalah menentukan topik, membatasi topik, menentukan bahan atau meteri penulisan dan terakhir menyusun kerangka karangan.

Tahap penulisan merupakan tahap pembahasan dan pengembangan gagasan menjadi suatu karangan yang utuh. Pada tahap ini kita harus mampu memilih kata dan istilah kata sehingga gagasan dapat dipahami pembaca. Kata-kata itu dirangkaikan menjadi kalimat-kalimat yang efektif. Selanjutnya kalimat-kalimat harus disusun menjadi paragraf-paragraf yang memenuhi persyaratan. Tulisan ini harus ditulis dengan ejaan yang berlaku disertai dengan tanda baca yang digunakan secara tepat. Di samping itu masih harus diketahui bagaimana menuliskan judul, sub judul, kutipan, catatan kaki dan daftar pustaka, dan sebagainya.

Tahap revisi merupakan tahap penelitian secara menyeluruh mengenai logika, sistematika, ejaan, tanda baca, pilihan kata, kalimat, paragraf, pengetikan catatan kaki dan daftar pustaka.

Berdasarkan uraian diatas Bahwa menulis merupakan suatu proses yang terdiri dari tahap pra penulisan, tahap penulisan dan tahap revisi.

\section{Gambar Seri sebagai Media Pembelajaran Bahasa.}

Gambar seri adalah gambar-gambar yang merupakan rangkaian kegiatan atau cerita dan disusun atau disajikan secara berurutan. Peneliti memilih media gambar seri sebagai penuntun atau membantu siswa untuk mengembangkan daya imajinasi untuk menjalin hubungan antara kejadian satu dengan kejadian yang lain dan saling berhubungan antara gambar satu dengan gambar yang lainnya sehingga siswa dapat merangkainya menjadi sebuah cerita.

Gambar seri dapat menggambarkan rangkaian cerita berdasarkan tempat, alur 
peristiwa, dan waktu kejadian cerita. Dari gambar seri tersebut, siswa dapat menyusun cerita yang runtut dan bervariasi.

Disamping itu media gambar seri dapat menimbulkan daya tarik bagi siswa, sehingga dengan demikian dapat membuat siswa lebih senang belajar dan pada akhirnya dapat memberikan hasil belajar yang baik

\section{METODE PENELITIAN}

\section{Jenis Penelitian}

Penelitian ini merupakan penelitian tindakan kelas (PTK) yang dilakukan secara bersiklus. Penelitian tindakan kelas ini ada dua siklus, masing - masing siklus terdiri atas empat kegiatan, yaitu : a. perencanaan (planning), b. pelaksanaan tindakan (action), c. observasi dan evaluasi (observation and evaluation), dan d. refleksi (reflection).

\section{Lokasi dan Subjek Penelitian}

Penelitian ini adalah penelitian tindakan kelas (PTK) yang berbasis kelas. Penelitian dilaksanakan di kelas VIII SMP 3 Pajjukukang Kabupaten Bantaeng Melalui Media Gambar Seri. Dengan jumlah subjek penelitian sebanyak 32 siswa tahun pelajaran 2015/2016. Penelitian ini direncanakan berlangsung di semester genap tahun ajaran 2015/2016. Dengan sasaran utama peningkatan siswa kelas VIII SMP 3 Pajjukukang Kabupaten Bantaeng menulis karangan argumentasi melalui media gambar seri. Lokasi penelitian ditetapkan berdasarkan pertimbangan masih ditemukan hasil belajar pada mata pelajaran bahasa Indonesia murid kelas VIII SMP 3 Pajjukukang Kabupaten Bantaeng pada tugas-tugas kelas yang diberikan oleh guru.

\section{Fokus Penelitian}

Penelitian ini mempunyai fokus utama yaitu aplikasi media gambar sebagai cara yang digunakan oleh guru untuk meningkatkan prestasi belajar siswa kelas VIII SMP 3 Pajjukukang Kabupaten Bantaeng pada pembelajaran bahasa Indonesia.

\section{HASIL DAN PEMBAHASAN}

\section{Hasil Penelitian}

Pelaksanaan tindakan yang dilakukan pada siklus II adalah mengulangi kembali tahap-tahap pada siklus I sambil mengadakan perbaikan dari kekurangan dan kekeliruan yang dilakukan pada siklus I.

Setelah merefleksi pelaksanaan siklus I diperoleh gambaran tindakan perbaikan yang akan dilaksanakan pada siklus II, yaitu setiap pertemuan diawali dengan pemberian apersepsi kemudian menyampaikan tujuan pembelajaran sehingga pokok materi menjadi lebih konkrit bagi siswa. Selain itu, penerapan pembelajaran menulis karangan argumentasi melalui media gambar seri juga dilakukan lebih maksimal sehingga siswa lebih bersemangat dan merasa tertantang dalam mengikuti pelajaran.

Pada siklus II semangat siswa dalam mengikuti pembelajaran melalui pembelajaran menulis karangan argumentasi melalui media gambar seri sudah mulai terbangun, ini terjadi karena siswa sudah mulai terbiasa dengan pembelajaran menulis karangan argumentasi melalui media gambar seri. Selain itu, pokok materi yaitu menulis karangan sudah mulai mereka kenal sehingga lebih memudahkan peneliti untuk menarik perhatian mereka mengikuti proses pembelajaran. 
Sebelum menyampaikan pokok materi dan tujuan pembelajaran, peneliti mencoba melakukan apersepsi hal ini dilakukan untuk menambah wawasan siswa. Setelah selesai memberikan apersepsi guru kemudian menjelaskan materi pembelajaran tentang menulis karangan argumentasi melalui media gambar seri kelas VIII SMP 3 Pajjukukang Kabupaten Bantaeng melalui media gambar seri dengan materi tersebut, mereka sudah mempunyai pengetahuan awal sebagai bekal untuk menguasai materi pelajaran keterampilan menulis karangan argumentasi.

Pada siklus kedua ini, baik pertemuan pertama maupun pertemuan kedua, siswa memperlihatkan ketertarikan untuk mengikuti proses pembelajaran. Mereka tidak lagi kelihatan bingung dan kaku seperti pada siklus pertama. Mereka terlihat sudah semangat dan sudah mengerti dengan semua aba-aba yang disampaikan selama pembelajaran, mereka juga langsung menyusun gambar seri secara berurutan, memberikan tema atau judul untuk paragraf dan mereka sudah mampu menulis karangan argumentasi melalui media gambar seri secara sendiri.

Kegiatan peneliti pada siklus ini tidak lagi terlalu berat, siswa-siswa dapat menulis karangan argumentasi sendirisendiri dengan baik dan tenang. Namun, peneliti tetap mengawasi siswa dan membimbing mereka terutama pada saat siswa mengerjakan lembar kerja siswa. Peneliti juga melayani siswa apabila ada kesulitan atau hal-hal yang tidak dimengerti dan dipahami oleh siswa. Seterusnya siswa kelihatan lebih giat dan antusias dalam mengikuti pelajaran ini sehingga suasana kelas menjadi lebih tertib.

Setelah semua siswa selesai mengerjakan lembar kerja siswa guru kemudian menunjuk beberapa siswa untuk menceritakan kembali isi karangan di depan kelas pada tahap ini sudah banyak siswa yang mampu melaksanakannya. Hal ini memberikan bukti bahwa siswa betul-betul sudah memahami dalam menulis paragraf melalui media gambar seri.

Kegiatan selanjutnya adalah guru mengevaluasi tiap siswa untuk menentukan skor individu pada setiap pertemuan. Evaluasi dimaksudkan untuk mengukur tingkat pemahaman murid pada pertemuan I dan II dalam menerima materi yang telah disampaikan. Bentuk evaluasinya adalah guru memberikan pertanyaan kepada siswa secara lisan mengenai materi yang telah dipelajari.

Pada siklus Ke II ini siswa sudah memperlihatkan hasil yang cukup memuaskan bagi peneliti. Hal ini terbukti dengan sudah banyak siswa yang mampu melaksanakan tiap tahapan yang ada pada materi pembelajaran menulis karangan argumentasi melalui media gambar seri. Hal tersebut terlihat pada peningkatan hasil belajar yang sangat bagus terhadap ketuntasan belajar siswa, dimana dari 32 jumlah siswa kelas VIII SMP 3 Pajjukukang Kabupaten Bantaeng melalui media gambar seri ada 17 orang siswa atau $53,13 \%$ yang memiliki nilai dengan kategori tinggi dengan interval nilai 7589. 15 siswa atau $46,87 \%$ yang berada pada kategori sedang dengan interval nilai 55-74, tidak terdapat siswa yang berada pada kategori kurang dan sangat kurang. Rata-rata kemampuan menulis karangan argumentasi siswa kelas VIII SMP 3 Pajjukukang Kabupaten Bantaeng melalui media gambar seri pada siklus II yaitu 73,59 .

Nilai hasil tes bahasa Indonesia menulis karangan argumentasi melalui media gambar seri pada siklus II pertemuan I dan II sesuai dengan data yang diperoleh di lapangan dengan hasil kuantitatif dipaparkan sebagai berikut:

Tabel 4.6. Tabulasi nilai akhir Peningkatan Menulis Karangan 
Argumentasi Kelas VIII SMP 3 Melalui Media Gambar Seri pada siklus Pajjukukang

Kabupaten Bantaeng

II

Keterampilan Menulis Karangan argumentasi Siklus II

\begin{tabular}{lllllll}
\hline No & \multicolumn{1}{c}{ Nama Siswa } & $\begin{array}{c}\text { Ide } \\
\text { Pokok }\end{array}$ & Diksi & $\begin{array}{c}\text { Kalimat } \\
\text { Efektif }\end{array}$ & Runtut & Nilai \\
\hline 1 & Yogi Sufyono & 20 & 20 & 20 & 20 & 80 \\
\hline 2 & Muh.Hidayah Kanar & 20 & 10 & 25 & 25 & 80 \\
\hline 3 & Muh. Anugrah Jufri & 20 & 15 & 20 & 15 & 70 \\
\hline 4 & Muh. Fiqih Ahmad & 20 & 15 & 25 & 15 & 75 \\
\hline 5 & A. Sakta Erlangga & 20 & 10 & 10 & 15 & 55 \\
\hline 6 & Muh. Fajar Rizal & 20 & 15 & 15 & 20 & 70 \\
\hline 7 & Radja Bintang P & 25 & 20 & 20 & 20 & 80 \\
\hline 8 & Muh. Salman Ali & 20 & 15 & 20 & 15 & 70 \\
\hline 9 & Muh. Nur Andika & 15 & 20 & 15 & 20 & 70 \\
\hline 10 & Muh. Naufal Abrar & 15 & 25 & 25 & 20 & 85 \\
\hline 11 & Eka Handayani & 25 & 10 & 20 & 20 & 70 \\
\hline 12 & Risna & 10 & 15 & 15 & 15 & 55 \\
\hline 13 & Dwi Febrianti & 10 & 25 & 25 & 15 & 75 \\
\hline 14 & Nurul Miftahul & 15 & 25 & 20 & 15 & 75 \\
\hline 15 & Rini Eka Safitri & 15 & 15 & 15 & 20 & 70 \\
\hline 16 & Putri Sabrina & 20 & 15 & 10 & 25 & 70 \\
\hline 17 & Risa Anisa & 25 & 15 & 20 & 20 & 80 \\
\hline 18 & Haswati Isnaeni & 25 & 20 & 15 & 20 & 85 \\
\hline 19 & Nur Fitri Wahyudin & 15 & 20 & 10 & 10 & 55 \\
\hline 20 & Andi Dewi Pramita & 15 & 15 & 25 & 20 & 75 \\
\hline 21 & Radiah Karim & 10 & 10 & 25 & 25 & 70 \\
\hline 22 & Reski Amalia & 20 & 10 & 25 & 25 & 80 \\
\hline 23 & Putri Putra Rimba & 25 & 15 & 25 & 15 & 80 \\
\hline 24 & Jehan Miranda & 15 & 10 & 20 & 25 & 70 \\
\hline 25 & Aryanti Arsad & 25 & 20 & 20 & 20 & 85 \\
\hline 26 & in Amelia & 15 & 10 & 15 & 15 & 55 \\
\hline 27 & Irfiana Nurul & 25 & 20 & 15 & 25 & 85 \\
\hline 28 & Nur Arwita Rahayu & 20 & 15 & 15 & 20 & 70 \\
\hline 29 & Pradiyasti Ayu & 20 & 20 & 20 & 20 & 80 \\
\hline 30 & Rosnita Makmur & 15 & 15 & 20 & 20 & 70 \\
\hline 31 & Dewi Angraeni & 25 & 20 & 15 & 15 & 75 \\
\hline 32 & Femiliati Muid & 25 & 25 & 10 & 20 & 85 \\
\hline & Jumlah & 610 & 530 & 595 & 610 & 2355 \\
\hline & Nilai Rata-rata & & & 73,59 & & \\
\hline & & & & & & \\
\hline
\end{tabular}

Tabel 4.7 Statistik Skor Penguasaan Murid pada Tes Siklus II

\begin{tabular}{cc}
\hline Statistik & Nilai Statistik \\
\hline Subjek & 32 \\
\hline
\end{tabular}




\begin{tabular}{cc}
\hline Skor ideal & 100 \\
\hline Skor terendah & 46,87 \\
\hline Skor tertinggi & 53,13 \\
\hline Skor rata-rata & 73,59 \\
\hline KKM & 65 \\
\hline
\end{tabular}

$$
\begin{aligned}
\text { Nilai rata }- \text { rata } & =\frac{\text { Nilai keseluruhan }}{\text { Jumlah siswa }} \\
& =\frac{2355}{32} \\
& =73,59
\end{aligned}
$$

Apabila skor hasil belajar dikelompokkan ke dalam lima kategori, maka diperoleh distribusi frekuensi dan persentase pada tabel 4.8 dan grafik 4.2

Tabel 4.8 Hasil Penelitian Kemampuan Menulis Karangan Argumentasi Siswa Siklus II.

\begin{tabular}{ccccc}
\hline Interval Nilai & Kategori & Frekuensi & Persentase & Rata-rata \\
\hline $90-100$ & Sangat Tinggi & 0 & 0 & \\
\cline { 1 - 4 } $75-89$ & Tinggi & 17 & 53,13 & \multirow{2}{*}{73,59} \\
\cline { 1 - 4 } $55-74$ & Sedang & 15 & 46,87 & \\
\hline $40-54$ & Rendah & 0 & 0 & \\
\cline { 1 - 4 } $0-39$ & Sangat Rendah & 0 & 0 & \\
\cline { 1 - 3 } & Jumlah & 32 & 100 & \\
\hline
\end{tabular}

Tabel 4.8 menujukkan bahwa kategori kemampuan menulis karangan argumentasi siswa kelas VIII SMP 3 Pajjukukang Kabupaten Bantaeng melalui media gambar seri setelah dilaksanakan proses pembelajaran melalui media gambar seri pada siklus II secara umum mengalami peningkatan, hal ini terlihat dari data 32 orang siswa yang menjadi sampel dalam penelitian ini terdapat 17 orang siswa atau $53,13 \%$ yang memiliki nilai dengan kategori tinggi dengan interval nilai 75-89. 15 siswa atau $46,87 \%$ yang berada pada kategori sedang dengan interval nilai 55-74, tidak terdapat siswa yang berada pada kategori kurang dan sangat kurang. Rata-rata kemampuan menulis karangan argumentasi siswa kelas VIII SMP 3 Pajjukukang Kabupaten Bantaeng melalui media gambar seri pada siklus II yaitu 73,59.

Berdasarkan tabel di atas, maka kategori hasil belajar kemampuan menulis karangan agumentasi siswa siklus II siswa kelas kelas VIII SMP 3 Pajjukukang Kabupaten Bantaeng Melalui Media gambar seri dapat digambarkan dalam grafik batang 4.1 


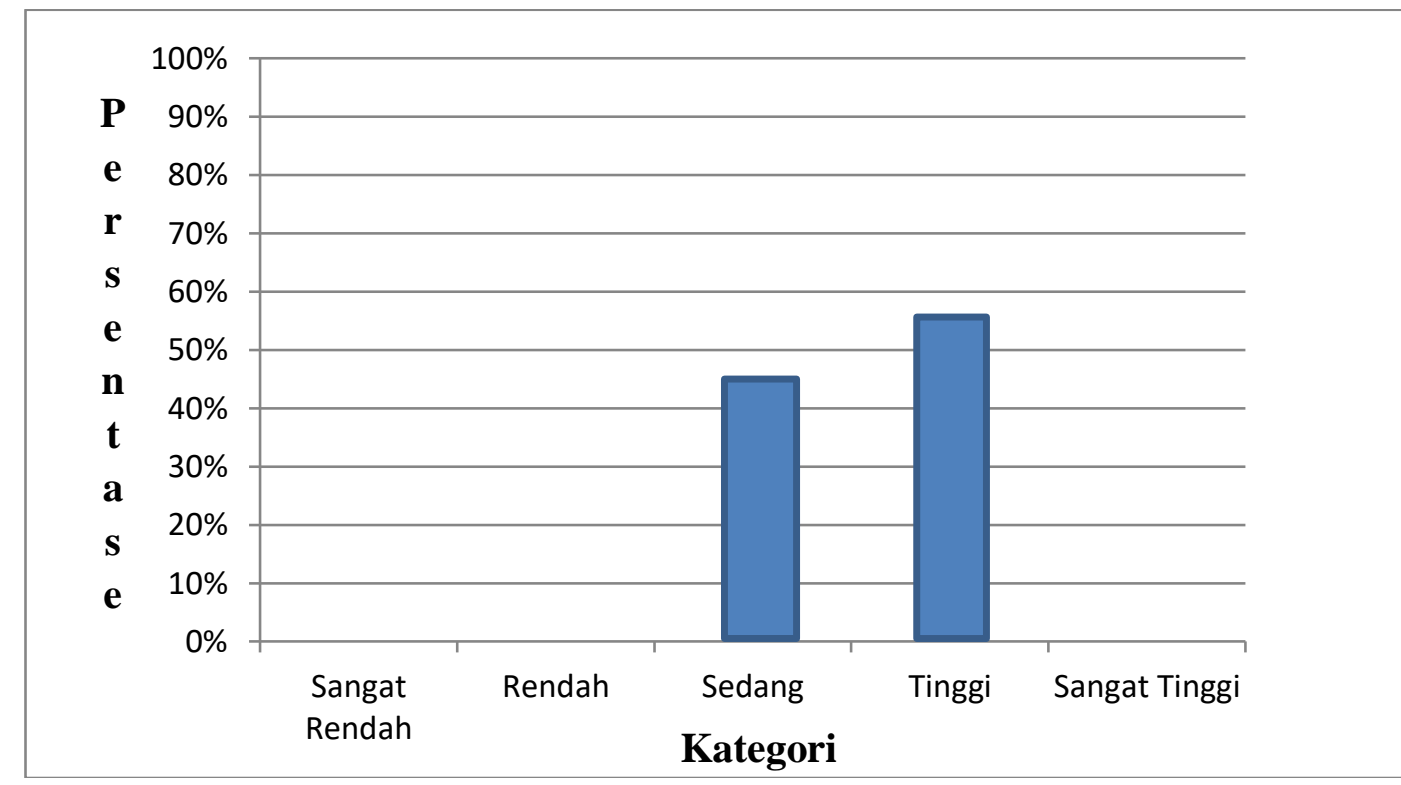

\section{Gambar 4.2 Grafik Batang Kategori Hasil Belajar Siswa Siklus II}

Berdasarkan tabel 4.8 dan grafik 4.2, maka dapat disimpulkan bahwa kategori kemampuan menulis karanngan argumentasi siswa kelas VIII SMP 3 Pajjukukang Kabupaten Bantaeng melalui media gambar seri setelah dilaksanakan proses pembelajaran melalui media gambar seri pada siklus II secara umum mengalami peningkatan, hal ini terlihat dari data 32 orang siswa yang menjadi sampel dalam penelitian ini terdapat 17 orang siswa atau $53,13 \%$ yang memiliki nilai dengan kategori tinggi dengan interval nilai $75-89.46,87 \%$ atau 15 orang siswa yang berada pada kategori sedang dengan interval nilai 55-74, tidak terdapat siswa yang berada pada kategori kurang dan sangat kurang. Rata-rata kemampuan menulis karangan argumentasi kelas VIII SMP 3 Pajjukukang Kabupaten Bantaeng Melalui media gambar seri pada siklus II yaitu 73,59 dan berada dalam ketegori tinggi.

Apabila hasil belajar siswa pada siklus II dianalisis, maka persentase ketuntasan belajar dapat dilihat pada tabel 4.9

Tabel 4.9 Deskripsi Ketuntasan Belajar Murid pada Siklus II

\begin{tabular}{cccc}
\hline Skor & Kategori & Frekuensi & Persentase \\
\hline $0-64$ & $\begin{array}{c}\text { Tidak } \\
\text { tuntas }\end{array}$ & 3 & 10,1 \\
$65-$ & Tuntas & 29 & 88,9 \\
100 & & 32 & 100 \\
\hline \multicolumn{2}{c}{ Jumlah } & 32 \\
\hline
\end{tabular}

Tabel 4.9 menunjukkan bahwa pada siklus II, siswa yang tuntas belajar semakin meningkat yaitu sebanyak 29 siswa yang tuntas sedangkan yang tidak tuntas 3 siswa.

Untuk melihat hasil belajar murid dalam setiap siklus tercatat pada tabel 4.10

Tabel 4.10 Peningkatan Hasil Belajar Siswa Pada Setiap Siklus

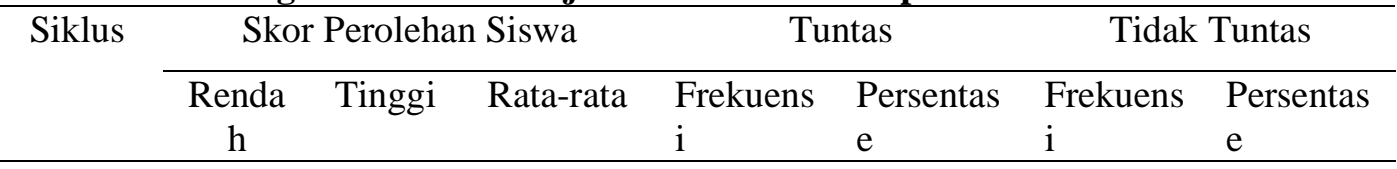




\begin{tabular}{lllccccc}
\hline Siklus 1 & 40 & 85 & 62,5 & 19 & 56,33 & 13 & 43,74 \\
Siklus 2 & 55 & 85 & 70 & 29 & 88,9 & 3 & 10,1 \\
\hline
\end{tabular}

Berdasarkan tabel 4.10 dapat dikemukakan bahwa terjadi peningkatan skor rata-rata peningkatan menulis karangan argumentasi kelas VIII SMP 3 Pajjukukang Kabupaten Bantaeng melalui media gambar seri , dari kategori sedang pada siklus I dengan skor rata-rata 63,13 dan KKM 65 dengan skor ideal 100. Pada siklus II dalam tabel juga menunjukkan bahwa pada siklus ini ketuntasan dalam kegiatan belajar mengajar tercapai. Hal ini ditandai dengan jumlah siswa yang mencapai ketuntasan belajar yang meningkat, yaitu dari 19 siswa pada siklus I meningkat menjadi menjadi 29 siswa pada siklus II.

Ketuntasan pada siklus ke II lebih banyak dari siklus I hal tersebut memberikan gambaran menulis karangan argumentasi kelas VIII SMP 3 Pajjukukang Kabupaten Bantaeng melalui media gambar seri mengalami peningkatan

Selama penelitian, selain terjadi peningkatan hasil belajar bahasa Indonesia pada siklus I dan siklus II tercatat sejumlah perubahan yang terjadi pada setiap siswa terhadap pelajaran khususnya bahasa Indonesia. Perubahan tersebut diperoleh dari lembar observasi pada setiap pertemuan yang dicatat pada setiap siklus. Lembar observasi tersebut untuk mengetahui perubahan sikap siswa selama proses belajar mengajar berlangsung di kelas pada siklus II disajikan pada tabel 4.11

Tabel 4.11 Hasil Observasi Aktivitas Siswa pada Siklus II

\begin{tabular}{|c|c|c|c|}
\hline No & $\begin{array}{l}\text { Aspek Yang } \\
\text { Diamati }\end{array}$ & $\begin{array}{c}\text { Jumla } \\
\text { h } \\
\text { Siswa }\end{array}$ & $\%$ \\
\hline 1 & Kehadiran & 32 & 100 \\
\hline 2 & $\begin{array}{l}\text { Menyimak } \\
\text { pengarahan guru }\end{array}$ & 31 & $\begin{array}{c}96,8 \\
7\end{array}$ \\
\hline 3 & $\begin{array}{l}\text { Menyalin/menca } \\
\text { tat }\end{array}$ & 31 & $\begin{array}{c}96,8 \\
7\end{array}$ \\
\hline 4 & $\begin{array}{l}\text { Bekerjasama } \\
\text { dengan teman }\end{array}$ & 30 & $\begin{array}{c}93,7 \\
5\end{array}$ \\
\hline 5 & $\begin{array}{l}\text { Mengajukan } \\
\text { pertanyaan }\end{array}$ & 23 & $\begin{array}{c}71,8 \\
7\end{array}$ \\
\hline 6 & $\begin{array}{l}\text { Menjawab } \\
\text { pertanyaan }\end{array}$ & 19 & $\begin{array}{c}59,3 \\
7\end{array}$ \\
\hline 7 & $\begin{array}{l}\text { Meminta } \\
\text { bimbingan guru }\end{array}$ & 27 & $\begin{array}{c}84,3 \\
7\end{array}$ \\
\hline
\end{tabular}

bahwa setelah dilaksanakan proses pembelajaran melalui media gambar seri pada siklus II dengan tahapan pembelajaran yang telah ditetapkan seperti pada siklus I tetapi telah dilakukan tindak lanjut terhadap hal-hal yang kurang pada siklus I, hasil observasi pada siklus II mengalami peningkatan keaktifan siswa dimana terlihat presentase tertinggi dari segi aktivitas siswa pada poin kehadiran $100 \%$, menyimak pengarahan guru sebesar $96,87 \%$, menyalin/mencatat sebesar $96,87 \%$, bekerja sama dengan teman sebesar 93,75\%, meminta pengarahan guru $84,37 \%$, dan mengajukan pertanyaan sebesar $71,87 \%$. Persentase terendah pada point menjawab pertanyaan $59,37 \%$.

Setelah merefleksi hasil pelaksanaan siklus I, diperoleh suatu gambaran tindakan yang akan dilaksanakan pada siklus II sebagai perbaikan dari tindakan yang dilakukan pada siklus I. 
Pada siklus II terlihat peningkatan dalam proses belajar mengajar. Hal ini terlihat dari keberanian siswa untuk bertanya tentang hal-hal yang kurang dipahami dan keaktifan mereka untuk memberi tanggapan terhadap suatu pertanyaan yang diajukan oleh guru. Selain itu, siswa yang melakukan aktivitas lain saat pembelajaran berlangsung juga semakin berkurang.

\section{Pembahasan}

\section{Siklus I}

Hasil penelitian menunjukkan bahwa model pembelajaran mempengaruhi akitivitas siswa dalam pembelajaran. Pada siklus I dengan proses pembelajaran melalui media gambar seri ternyata masih belum berhasil dalam meningkatkan aktivitas siswa. Setelah dilakukan beberapa perbaikan mengenai kekurangan tindakan siklus I, maka aktivitas siswa dari $(64,73 \%)$ keaktifan siswa pada siklus I menjadi $(86,16 \%)$ keaktifan siswa dalam proses pembelajaran pada siklus II. Hal ini demikian karena penggunaan melalui media gambar seri semakin ditingkatkan dengan memberikan motivasi belajar kepada siswa.

Tindakan pemahaman konsep merupakan langkah untuk mendesain proses pembelajaran seperti yang diharapakan dengan tujuan untuk meningkatkan kemampuan menulis karangan argumentasi siswa. Melalui media gambar seri yang baik akan menjadikan siswa lebih aktif dalam proses pembelajaran. Dengan keaktifan yang sangat tinggi akan mempengaruhi kemampuan menulis karangan argumentasi siswa. Hal tersebut sejalan dengan hasil penelitian tindakan kelas yang dilakukan melalui media gambar seri. Penggunaan media gambar seri ini merupakan proses pembelajaran yang efektif untuk meningkatkan aktivitas siswa. Terbukti selama 2 (dua) siklus dalam proses penelitian ini, aktivitas siswa mengalami peningkatan dari siklus I ke siklus II.

Kemampuan menulis karangan siswa kelas VIII SMP 3 Pajjukukang Kabupaten Bantaeng Melalui media gambar seri pada siklus I berdasarkan kategori kemampuan menulis karangan argumentasi siswa sudah tergolong sedang dengan rata-rata 63,13. Pada siklus I dari 32 orang siswa tidak ada siswa yang berada pada kategori sangat tinggi dengan interval nilai 90-100. 6 orang siswa atau 15,63\% yang memiliki nilai dengan kategori tinggi. 20 orang siswa atau $62,5 \%$ yang berada pada kategori sedang dengan interval nilai 557. 6 orang siswa atau $21,87 \%$ berada pada ketegori sangat kurang. Tidak ada siswa yang berada pada kategori sangat rendah dengan interval nilai 0-39. Rata-rata kemampuan menulis karangan argumentasi pada siswa kelas VIII SMP 3 Pajjukukang Kabupaten Bantaeng melalui media gambar seri pada siklus I yaitu $63,13 \%$.

Dalam pelaksanaan proses pembelajaran yang dilakukan pada penelitian pertemuan pertama pada siklus I penulis merasakan beberapa kesulitan yaitu:

a. Persiapan siswa yang terlalu lama sebelum memulai belajar bahasa Indonesia, hal ini dikarenakan belajar bahasa Indonesia dimulai setelah jam istirahat, sehingga perlu mengembalikan suasana agar kondusif.

b. Siswa masih terlihat bingung dalam mengurutkan gambar seri.

c. Siswa masih kesulitan untuk menentukan tema dalam menulis paragraf.

\section{Siklus II}

Menanggapi hasil belajar bahasa Indonesia siswa pada siklus I di kelas kelas VIII SMP 3 Pajjukukang Kabupaten 
Bantaeng melalui media gambar seri, maka pada siklus II dilakukan upaya pembelajaran menulis karangan argumentasi melalui media gambar seri secara maksimal agar proses pembelajaran bahasa Indonesia dapat lebih mampu mendukung peningkatan kemampuan belajar dan hasil belajar murid. Demikian pula memberikan motivasi dan penguatan secara lebih intensif agar semua siswa berperan lebih aktif dalam kegiatan belajar, khususnya dalam menjawab pertanyaan yang pada gilirannya dapat meningkatkan hasil belajar siswa.

Hasil tes siklus kedua menunjukkan bahwa hasil belajar bahasa Indonesia 32 orang siswa yang menjadi sampel dalam penelitian ini terdapat 17 orang siswa atau $53,13 \%$ yang memiliki nilai dengan kategori tinggi dengan interval nilai 7589. 15 orang siswa atau $46,87 \%$ yang berada pada kategori sedang dengan interval nilai 55-74, tidak terdapat siswa yang berada pada kategori kurang dan sangat kurang. Rata-rata kemampuan menulis karangan argumentasi siswa kelas VIII SMP 3 Pajjukukang Kabupaten Bantaeng melalui media gambar seri pada siklus II yaitu 73,59.

Berdasarkan perubahan - perubahan yang terjadi pada siklus II menunjukkan bahwa hasil belajar bahasa Indonesia dengan menulis karangan argumentasi melalui media gambar seri memberikan dampak positif bagi siswa. Hal ini berarti menulis karangan argumentasi melalui media gambar seri telah dilaksanakan dengan baik dan telah mencapai indikator keberhasilan pembelajaran dari aspek pencapaian standar KKM dan ketuntasan belajar yang mencapai 73,59\%. Demikian pula keaktifan siswa mengikuti pelajaran semakin tinggi yang ditandai antusiasme siswa dalam menyimak penjelasan guru, mempelajari materi pelajaran, menjawab pertanyaan guru, melakukan refleksi, mencatat materi pelajaran, dan menyimpulkan materi pelajaran bahasa Indonesia sehingga hal tersebut mendukung penguasaan terhadap materi dalam pembelajaran menulis karangan argumentasi pada siswa kelas VIII SMP 3 Pajjukukang Kabupaten Bantaeng melalui media gambar seri

\section{KESIMPULAN DAN SARAN}

\section{Kesimpulan}

Berdasarkan hasil penelitian dan pembahasan yang telah diuraikan, maka peneliti menyimpulkan hal-hal sebagai berikut :

1. Keaktifan siswa kelas VIII SMP 3 Pajjukukang Kabupaten Bantaeng melalui media gambar seri melalui media gambar seri kemampuan menulis karangan argumentasi mengalami peningkatan dari $64,73 \%$ keaktifan siswa pada siklus I menajdi $86,16 \%$ keaktifan siswa pada siklus II.

2. Rata-rata kemampuan menulis karangan argumentasi pada siswa kelas VIII SMP 3 Pajjukukang Kabupaten Bantaeng melalui media gambar seri pada siklus I yaitu 63,13. Rata-rata kemampuan menulis paragaraf siswa kelas VIII SMP 3 Pajjukukang Kabupaten Bantaeng melalui media gambar seri pada siklus II yaitu 73,59.

3. Hasil penelitian mengenai kemampuan menulis karangan argumentasi siswa kelas VIII SMP 3 Pajjukukang Kabupaten Bantaeng melalui media gambar seri melalui media gambar seri mengalami peningkatan dari siklus I ke siklus II.

\section{Saran}

Kepada guru hendaknya selalu menciptakan pembelajaran bahasa Indonesia yang menyenangkan 
diantaranya dengan penggunaan berbagai media, misalnya media gambar seri. Media gambar seri hendaknya dipilih gambar yang mendidik. Selain itu, guru hendaknya sellau meningkatkan profesionalisme sehingga guru mampu melaksanakan program pembelajaran sesuai tuntunan kurikulum.

\section{DAFTAR PUSTAKA}

Adi Prasetya, Yudhistira. 2011. Ringkasan Teori dan Evaluasi Bahasa Indonesia. Jakarta: Grasindo.

Ahmad.Abdul Karim. 2007. Media Pembelajaran. Makassar : Badan Penerbit UNM Makassar.

Arsyad, Azhar. 2011. Media Pembelajaran. Jakarta: Rajawali Pers.

Edgar Dale dalam Abdul Karim Ahmad dalam bukunya Media pembelajaran(2007:2).

Hamalik (1994:15) mengemukakan manfaat media pembelajaran.

Keraf, Gorys. 2004. Komposisi. Jakarta: Nusa Indah.

Oemar Hamalik dalam Ahmad Abdul Karim. $2007 \quad$ Media Pembelajaran. Makassar: Badan penerbit UNM Makassar.

Saddhono, Kundharu \& Slamet, S. Y. 2012. Meningkatkan Keterampilan Berbahasa Indonesia (Teori dan Aplikasi). Bandung: Karya Putra Darwati.

Soeparno dalam Ahmad Abdul Karim. 2007 Media Pembelajaran.
Makassar: Badan penerbit UNM Makassar.

Sudjana dan Rivai (1992:2) mengemukakan manfaat media pembelajaran dalam proses belajar mengajar

Suparno dan M. Yunus.2003. Keterampilan Dasar Menulis. Jakarta: Universitas Terbuka.

Tampubolon. 1987. Kemampuan Membaca Teknik Membaca Efektif dan Efisien. Bandung : Angkasa.

Tarigan (1981:1). Membina Keterampilan Menulis Paragraf dan Pengembangannya. Bandung: Angkasa.

Tarigan (1986:21). Menulis Sebagai Keterampilan Berbahasa. Bandung : Angkasa

Tarigan.Henry Guntur.2008. Menulis Sebagai Suatu Keterampilan Berbahasa .Bandung: Angkasa.

Keraf, Gorys. 2004. Komposisi. Jakarta: Nusa Indah.

Yusuf Hadi Miarso dalam Ahmad Abdul Karim. $2007 \quad$ Media Pembelajaran. Makassar: Badan penerbit UNM Makassar 